\author{
Natalia Wasilewska \\ Jan Kochanowski University in Kielce
}

Tatiana Bludova,

Volodymyr Tokar

Oleksiy Kudenko

Kyiv National Economic University named after Vadym Hetman

\title{
EVALUATION OF TARGET MARKET SEGMENTS FOR ENTERPRISES
}

\begin{abstract}
The purpose of the article is to substantiate the emergence of new - and the development of existing - factors and segmentation criteria for meeting consumer needs and increasing the efficiency of marketing activities for Ukrainian enterprises under modern market conditions. The object of the research is to analyze the process of development and any increases in the effectiveness of marketing segmentation. The subject of research is the theoretical, methodical and practical provisions of the formation of targeted marketing segmentation for the markets of Ukrainian enterprises. The goal of the research is to evaluate the direction and type of market segmentation that determines future target segments for enterprises and their share of existing markets.

We present the characteristics of enterprises that work on market relations for the production and sale of computer devices that provide network connections. Our method was to estimate the direction and type of market segmentation in order to determine the prospective segments for such enterprises and their share of the existing market. In order to evaluate the attractiveness of target segments for Ukrainian enterprises, a survey was conducted to validate customer reactions. The analyzed variables included: the length of time a person uses his/her computer device; the reasons for possible changes and important settings when choosing a computer device; the timeframe for buying a computer device. The results of the questionnaire are separated by gender, social and geographic factors, as well as by family composition and age of respondents, taking into account the stages of their life cycle, as well as their educational level and professions - for three enterprises. Particular attention was paid to the psychographic factors of occupation and social class. The questionnaire also contained a self-assessment section on the psychological qualities of the consumer and on their psychography, which we analyzed.

The hypotheses presented by individual factors and the consumer segment, separated by the results of the survey, and the analysis of the respondents' answers, are presented. Confirmation of the hypotheses and isolation of the consumer segment are given.
\end{abstract}

Keywords: market segmentation, psychographic factors, relevant factors, questionnaires, respondents

JEL Codes: M31

\section{Introduction}

Today, the importance of segmentation as an effective tool for marketing activity of a business enterprise is beyond doubt. The vast majority of successful companies in all industries use segmentation as an effective tool to gain sustainable competitive advantage. 
By separating consumer segments and providing them with relevant goods and services, a company can retain and expand its market share, obtain target profits and make optimal use of available resources. Accordingly, segmentation is a sensitive and dynamic tool that must respond quickly to changes in the social and economic life of society.

Table 1. Market segmentation methods

\begin{tabular}{|c|c|}
\hline $\begin{array}{l}\text { Market segmentation } \\
\text { methods }\end{array}$ & Application and essence \\
\hline $\begin{array}{l}\text { Segmentation by } \\
\text { benefits } \\
\text { McDonald M, Dunbar I } \\
(2004)^{1}\end{array}$ & $\begin{array}{l}\text { The method is based on the construction of a model of consumer behavior, and } \\
\text { involves three consecutive stages: } \\
\text { 1. Determining the benefits that interest the consumer, and their importance } \\
\text { 2. Identifying differences in lifestyle that lead to benefit segmentation. } \\
\text { Consumer grouping by these estimates. } \\
\text { 3. Determining whether the benefit segments have a variety of product views } \\
\text { and competing brands. }\end{array}$ \\
\hline $\begin{array}{l}\text { Segmentation network } \\
\text { building Dolnicar S, } \\
\text { Leisch F }(2010)^{2}\end{array}$ & $\begin{array}{l}\text { The method is used at the macro-segmentation level to highlight the } \\
\text { underlying markets. A combination of variables characterizing functions, } \\
\text { consumers, and technology is considered. According to the results of the } \\
\text { analysis, there are primary segments that give the maximum percentage of } \\
\text { benefits. }\end{array}$ \\
\hline $\begin{array}{l}\text { Multi-dimensional } \\
\text { classification } \\
\text { Wood SN }(2006)^{3}\end{array}$ & $\begin{array}{l}\text { The essence of the method lies in the simultaneous, multidimensional } \\
\text { classification of signs of consumer behavior. Consumers that are similar in a } \\
\text { number of characteristics (e.g., demographic, psychographic, etc.) are } \\
\text { combined in one type. The degree of similarity between people of one type } \\
\text { should be higher than that of people of different types. The method enables } \\
\text { segmentation of consumers by the most important attribute. }\end{array}$ \\
\hline $\begin{array}{l}\text { Division by groups } \\
\text { Cliff K }(2009)^{4}\end{array}$ & $\begin{array}{l}\text { Objects are grouped consecutively. Usually, one of the features is recorded as } \\
\text { system-forming. This allows the formation of subgroups in which this feature } \\
\text { is more important than features of other consumers of the product. }\end{array}$ \\
\hline $\begin{array}{l}\text { Functional maps } \\
\text { Dolnicar S, Leisch F } \\
(2017)^{5}\end{array}$ & $\begin{array}{l}\text { The method involves double segmentation by product and consumer. Such } \\
\text { aspects may be: } \\
\text { - single-factor, when double market segmentation is performed by one factor } \\
\text { for a homogeneous product group; } \\
\text { - multifactorial, when analyzing to which consumer groups a specific product } \\
\text { model is assigned, and which parameters are most important for market } \\
\text { promotion. }\end{array}$ \\
\hline
\end{tabular}

Source: Developed by authors.

At the same time, changes in consumer behavior, preferences and consumer lifestyles lead to the emergence of new and development of existing factors and segmentation criteria to better meet consumer needs and increase the efficiency of enterprise marketing activities. Kumar $(2008)^{6}$ has constructed a blockchain based on

${ }^{1}$ McDonald M, Dunbar I (2004). Market Segmentation: How to Do It, How to Profit from It.Elsevier ButterworthHeinemann. Oxford.

${ }^{2}$ Dolnicar S, Leisch F (2010) Evaluation of structure and reproducibility of cluster solutions using the bootstrap. Mark Lett 21:83-101.

${ }^{3}$ Wood SN (2006) Generalized additive models: an introduction with R. Chapman and Hall/CRC, Boca Raton ${ }^{4}$ Wallenburg, C. M. and Lukassen, P. (2011). Proactive Improvement of Logistics Service Providers as Driver of Customer Loyalty, European Journal of Marketing, Vol. 45, No: 3, pp. 438-454.

${ }^{5}$ Dolnicar S, Leisch F (2017) Using segment level stability to select target segments in data-driven market segmentation studies. Mark Lett 28(3):423-436.

${ }^{6}$ Kumar, N. (2008). Marketing as Strategy Leading to Successs, Prague: Grada Publishing (in Czech). 
the management of the value of networks from manufacturers to end consumers and offers a comprehensive perception of the value chain.. Kotler, P. and Keller, L.G. (2013) ${ }^{7}$ analyze the increased value for the customer. Kowalkowski $(2011)^{8}$ views customer value as an integrated configuration. Kourdi, J. (2011) ${ }^{9}$ states that the form and design of products and services should also reflect the big picture.

Wallenburg, C. M. and Lukassen, P. (2011) ${ }^{10}$ emphasize the importance of intangible attributes of customer value (emotional and social), which constitute assets that lead to deepening customer relationships. E-commerce behavior is carefully described by Wiedmann et al., 2010 ${ }^{11}$. Baron, S. and Harris, K., $2010^{12}$ note that the concept of customer satisfaction can lead to long-term relationships with customers. Table 1 demonstrates the methods of segmentation.

It is worth mentioning, that the multidimensional segmentation foresees the building of consumer groups in terms of psychographics, demographics, socio-economic or other indicators, as noted by Wood, S. N. (2006). As a result, the researcher receives several groups of consumers who are similar.

Dolnicar S, Leisch F (2017) emphasize that the functional card method identifies a group of consumers meeting certain product characteristics.

Therefore, market segmentation methods are interconnected, as has been proved by Anderson, E. W., Fornell, C., \& Mazvacheryl, S. K. (2004) ${ }^{13}$ (Table 2).

Table 2. Market segmentation factors

\begin{tabular}{|c|c|c|}
\hline Types of factors & Objective & Subjective (psychographic) \\
\hline $\begin{array}{c}\text { Non-specific } \\
\text { marketing factors }\end{array}$ & $\begin{array}{c}\text { Demographic: } \\
\text {-sex; } \\
\text {-age. }\end{array}$ & $\begin{array}{c}\text { Personal features: } \\
\text { - psychotype, } \\
\text { - ideology, } \\
\text { - perception and benefits, } \\
\text { - behavior. }\end{array}$ \\
\hline $\begin{array}{c}\text { Marketing- } \\
\text { specific factors }\end{array}$ & $\begin{array}{c}\text { Socio-economic: } \\
\text { - income; } \\
\text { - education; } \\
\text { - consumer lifecycle; } \\
\text { - classification of residential areas; } \\
\text { - use of media. }\end{array}$ & $\begin{array}{c}\text { Lifestyle: } \\
\text { - values; } \\
\text { - hobby; } \\
\text { - entertainment; } \\
\text { - style of interaction with other people; } \\
\text { - judgments. }\end{array}$ \\
\hline
\end{tabular}

Source: Developed by authors.

\footnotetext{
${ }^{7}$ Kotler, P. and Keller, L.G. (2013). Marketing Management, Prague: Grada Publishing (in Czech).

${ }^{8}$ Kowalkowski, CH. (2011). Dynamics of Value Propositions: Insights from Service-Dominant Logic, European Journal of Marketing, Vol.45, No:1/2, pp. 277-294.

${ }^{9}$ Kourdi, J. (2011). Marketing Century: How Marketing Drives Business and Shapes Society, Chichester: John Wiley \& Sons.

${ }^{10}$ Wallenburg, C. M. and Lukassen, P. (2011). Proactive Improvement of Logistics Service Providers as Driver of Customer Loyalty, European Journal of Marketing, Vol. 45, No: 3, pp. 438-454.

${ }^{11}$ Wiedmann, K.P., Hennigs, N., Pankalla, L., Kassubek, M., Seegebarth, B. and Reeh, M.O. (2010). Online Distribution of Pharmaceuticals: Investigating Relations of Consumers' Value Perception, Online Shopping Attitudes and Behaviour in a Epharmacy Context, Journal of Customer Behaviour, Vol. 9, No. 2, pp. 175-199.

12 Baron, S. and Harris, K. (2010). Toward an Understanding of Customer Perspectives on Experiences. Journal of Services Marketing, 24(7), pp. 518-531

${ }^{13}$ Anderson, E. W., Fornell, C., \& Mazvacheryl, S. K. (2004).Customer satisfaction and shareholder value.Journal of Marketing, 68(4), 172-185. Retrieved from http://dx.doi.org/10.1509/jmkg.68.4.172.42723.
} 
The methodological basis of the research is the specific research methods: analytical and logical method, method of analysis and synthesis to distinguish modern marketing strategies according to the level of market segmentation and their role in the process of strategic marketing, as well as analysis of questionnaires to approve customer reactions.

However, there are a number of issues related to the marketing analysis of the Ukrainian market vis-à-vis the global market of computer devices that provide network connections, as well as the study of the segmentation levels of the Ukrainian market. They require new methodological approaches to identify current segmentation criteria confirming the relevance of existing segments, which is one of the most urgent problems for the marketing activity of enterprises under current conditions.

Thus today, market segmentation is not just an option, but also a necessity for any enterprise that seeks to operate effectively and to develop in the face of increased competition and growing demands of potential and existing consumers. Nevertheless, in order to be effective, market segmentation should not be used as an isolated tool, but should complement and develop the overall corporate strategy of enterprise development.

Therefore, identifying new topical segmentation criteria along with confirming the relevance of existing segmentation is one of the most pressing problems for an enterprise's marketing activities in today's context.

In order to evaluate the attractiveness of target segments of Ukrainian enterprises, a survey was conducted to validate customer reactions.

\section{Research result}

The results and analysis of questionnaires to validate customer reactions

Table 3 shows the companies that work in the field of market relations for the manufacture and sale of computer devices with network connectivity.

Table 3. Characteristics of enterprises for the production and sale of computers

\begin{tabular}{|c|l|}
\hline $\begin{array}{c}\text { Enterprise } \\
\text { (Market period) }\end{array}$ & \multicolumn{1}{c|}{ Company profile } \\
\hline $\begin{array}{c}\text { Samsung Electronics } \\
\text { Ukraine Company } \\
\text { (20 years) }\end{array}$ & $\begin{array}{l}\text { Samsung Electronics is the world leader in the production of telecommunications and } \\
\text { digital media equipment, as well as in the field of digital convergence technology. } \\
\text { Wholesale of electrical and electronic goods - digital media (LCD panels and } \\
\text { software) }\end{array}$ \\
\hline $\begin{array}{l}\text { Manufacturer of the full range of TM Impression computer systems: desktops, } \\
\text { laptops, servers (including blade systems), graphic stations and a wide range of } \\
\text { consumer solutions (tablets, monoblocks, laptops, ultrabooks). The leader in the } \\
\text { volume of production and sales of desktops in Ukraine, the distributor of IT products } \\
\text { of leading world manufacturers, providing IT consulting, design, implementation of } \\
\text { corporate networks, customer support. Exports goods to the following countries: } \\
\text { Kazakhstan, South Korea, The company imports goods from the following countries: } \\
\text { China, Hong Kong (Hong Kong), South Korea, The Netherlands, Russia }\end{array}$ \\
$\begin{array}{l}\text { Largest manufacturer of PV energy products, integrated circuits and silicon wafers in } \\
\text { Eastern Europe. The plant is one of the five largest manufacturers of photovoltaic } \\
\text { modules and autonomous power plants based on them. The plant manufactures and } \\
\text { offers a complete range of PV power products, ranging from photovoltaic converters } \\
\text { of any size and shape, mono or polycrystalline modules, from 1 to 200 watts, and } \\
\text { ending with solar chargers and power supplies of various power and functionality }\end{array}$ \\
\hline
\end{tabular}

Source: Developed by authors. 
Bludova $(2005)^{14}$ notes that when conducting any type of questioning, it is necessary to determine the size of the sample. Note that the sample size is determined by the formula:

$$
n=\frac{n_{0}}{1+\frac{n_{0}-1}{N}} ;(1)
$$

where $N$ is the size of the aggregate - the number of potential consumers of products of selected enterprises in the area; $n$ is the minimum sample size given that the sample of consumers who buy computer devices with online connectivity in online stores selling products of a select group of companies is being investigated.

The following sample size was determined for the enterprises: 156 persons Samsung Electronics Ukraine Company; 143 persons - Navigator; 137 persons are "Quasar".

Figure 1 shows a breakdown of the answers to the question: "How much time per day do you use your computer device?"

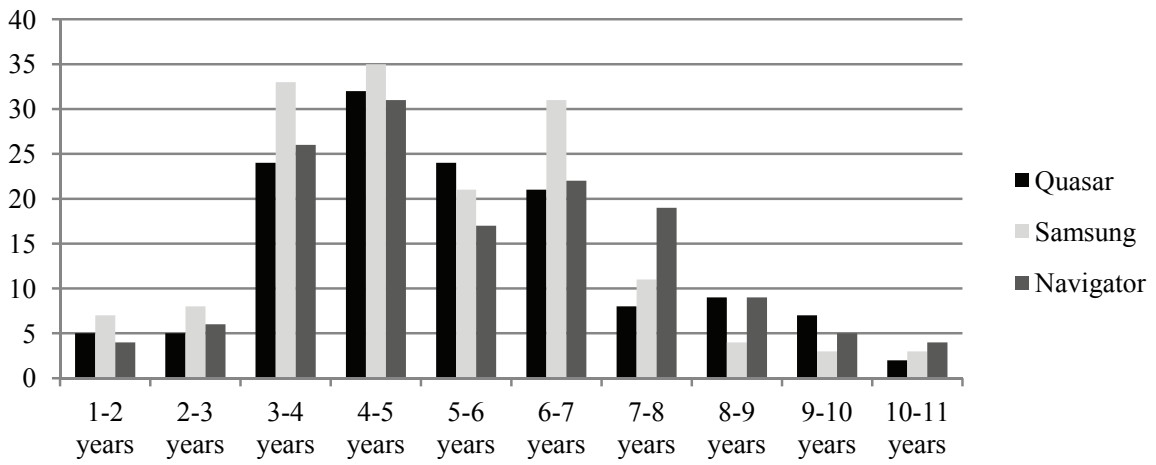

Figure 1. The length of time you use your computer device Source: Developed by authors.

Note that in the life of each person there comes a time when it becomes necessary to change an existing computer or buy a new one. Of course, in any configuration - a new or first computer device will satisfy almost all expectations for innovative technology, though it may be far from the optimal choice. And it is unwise to spend money on what will quickly depreciate. In this case, it is somewhat easier for experienced users to make the right choice because they are aware of their preferences and have an idea of what tasks they will be faced with when choosing a new computer device.

Figure 2 shows the percentages of the answers to the reasons for the possible change of the computer device. Therefore, we see the need to identify the segment of consumers who want to buy a new model of computer device. Note that if, for example, a consumer uses a computer device to visit websites, play simple games (such as Alawar or mini-games that are on social networks), and also to listen to music on a computer device, then a powerful computer is needed.

${ }^{14}$ T. Bludova (2005). Probability Theory: Educ. guide Lviv. NBU National Bank, 2005-319 p. (In Ukrainian ) 
A simple computer with an integrated video card will suffice for simple tasks. If the consumer wants to watch HD movies on a computer and play modern games with threedimensional graphics, then the parameters of the computer device should be powerful enough, especially the video card, which should be powerful and not embedded.

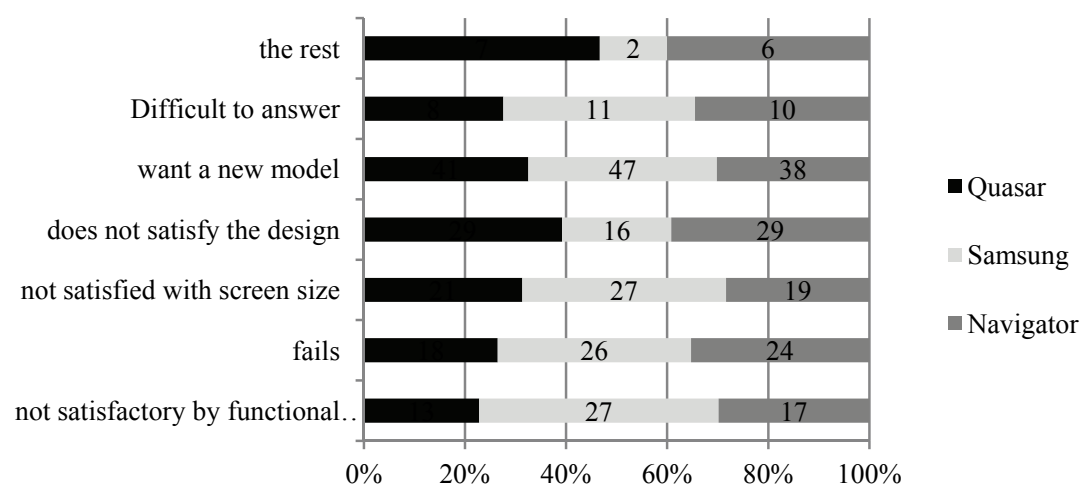

Figure 2. An analysis of the reasons for a possible change of computer device Source: Developed by authors.

Figure 3 shows the percentages of the questionnaire response to the question of what options are most important to the consumer when choosing a computer device.

The results in Figure 3 show that in the first place there is a segment of consumers for whom it is important to have the latest operating system, and then the size of the built-in and RAM is an important factor. Indeed, the operating system is one of the most important components of the software. This is a suite of programs that allow you to manage your computer's hardware and software resources, plan for efficient use of its resources, and solve tasks at the user's request.

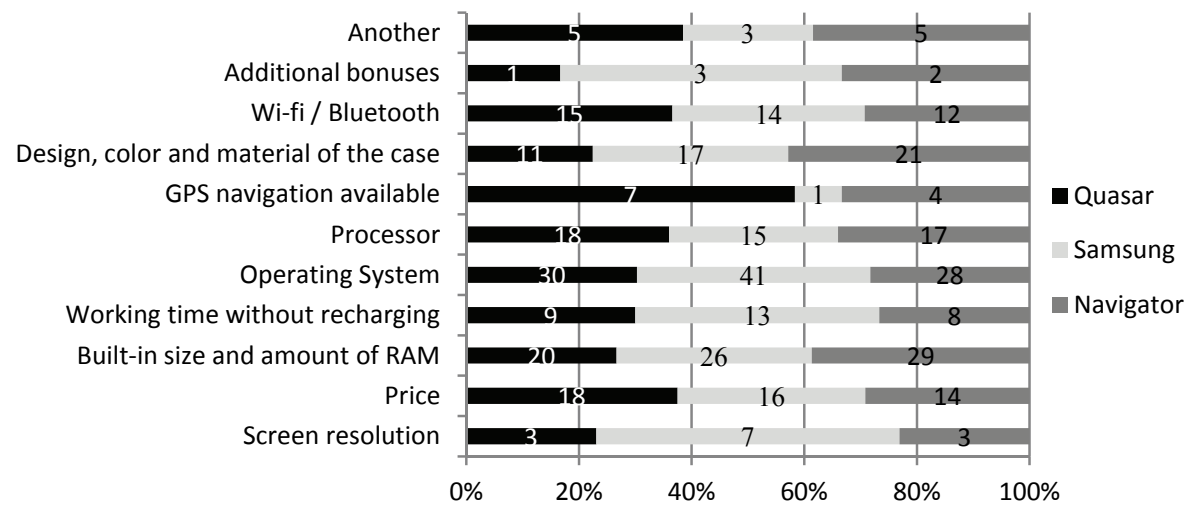

Figure 3. An analysis of the most important options when choosing a computer device Source: Developed by authors 
The operating system ensures the interaction of programs with external devices and with each other; allocates RAM; recognizes various situations that occur when executing programs by notifying the user. RAM, in turn, is a temporary repository of files that are often used or copied. As a rule, 4 Gigabytes of RAM will be enough for a computer of unpretentious users, but the advanced user will need all 8 Gigabytes of RAM.

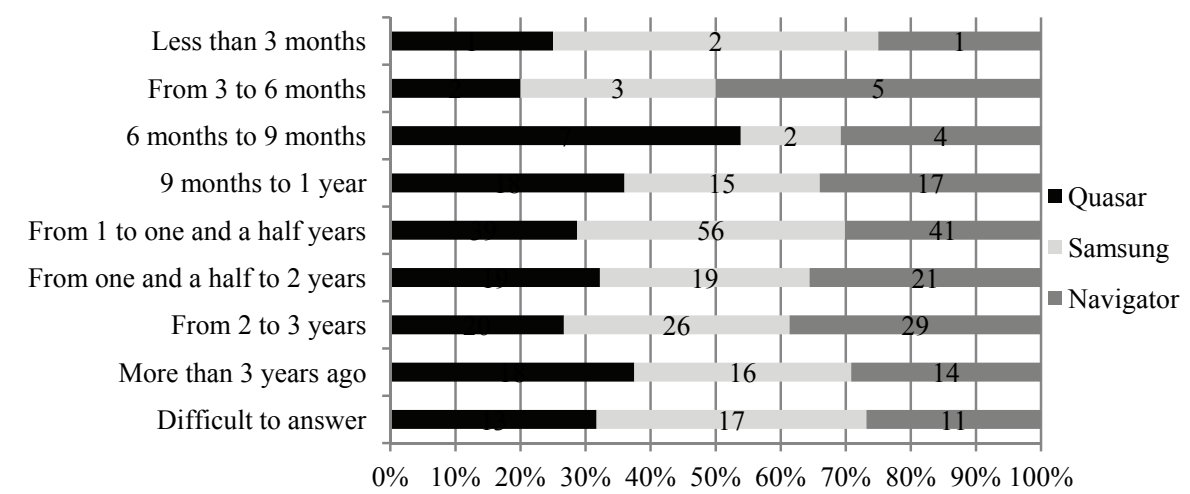

Figure 4. Analysis of the purchase time of a computer device Source: Developed by authors.

Figure 4 shows the percentages of the questionnaire response to the question of how long ago the computer device you used was purchased. As shown in Figure 4, a significant number of consumers purchased a computer device from one to one and a half years ago. This is to say that the modern user wants to keep up with all the news in the space of improving computer devices.

It should be noted that recently scientists are working on the creation of a computer that can understand human voice commands. It has been proven that electronic circuits in computers of the new generation are similar to the structure of the human brain, so such computers are capable of learning on their own. In the near future, a computer user will speak to their machine in their native language. This means that your computer is even more accessible and much easier to manage.

\section{Gender, social and geographical segmentation survey results}

Undoubtedly, technique is an integral part of the everyday life of a contemporary, regardless of gender. At the wheel of cars - both men and women, similar to the use of computer devices. This statement is true and for Internet users, which is confirmed by sociological data of 2016, there is no gender imbalance (Table 4).

Table 4. Gender Internet users

\begin{tabular}{|c|c|c|}
\hline Sociological Institution & Male users, $\%$ & Female users, $\%$ \\
\hline KMIC & 51 & 49 \\
\hline GfK Ukraine & 50,9 & 49,1 \\
\hline InMind & 50 & 50 \\
\hline
\end{tabular}

Source: Developed by authors. 
Table 5. Survey results for geographic segmentation

\begin{tabular}{|l|r|r|r|r|}
\hline \multicolumn{1}{|c|}{ Enterprise } & The sample size & Males & Females & Nationality (Ukrainians) \\
\hline Quasar & 137 & $69-50,3 \%$ & $68-49,7 \%$ & $95,7 \%$ \\
\hline Samsung & 156 & $86-55,1 \%$ & $70-44,9 \%$ & $91,3 \%$ \\
\hline Navigator & 143 & $81-56,6 \%$ & $62-43,4 \%$ & $93,9 \%$ \\
\hline
\end{tabular}

Source: Developed by authors.

To confirm this pattern, a survey was conducted on the gender of consumers of computer devices and the results for determining geographical factors are presented in Table 5. Almost all respondents are Ukrainian, and on average half of respondents are male and half are female.

Today, an interesting demographic question arises regarding the identification of families and their characteristics. This issue plays an important role in market segmentation. After all, families and their "varieties" are many. Therefore, the right definition of the focus of the society will help to conduct the right marketing policy, taking into account the segmentation.

Figure 5 presents the survey results, which show the distribution of the three enterprises by family composition and age of respondents.
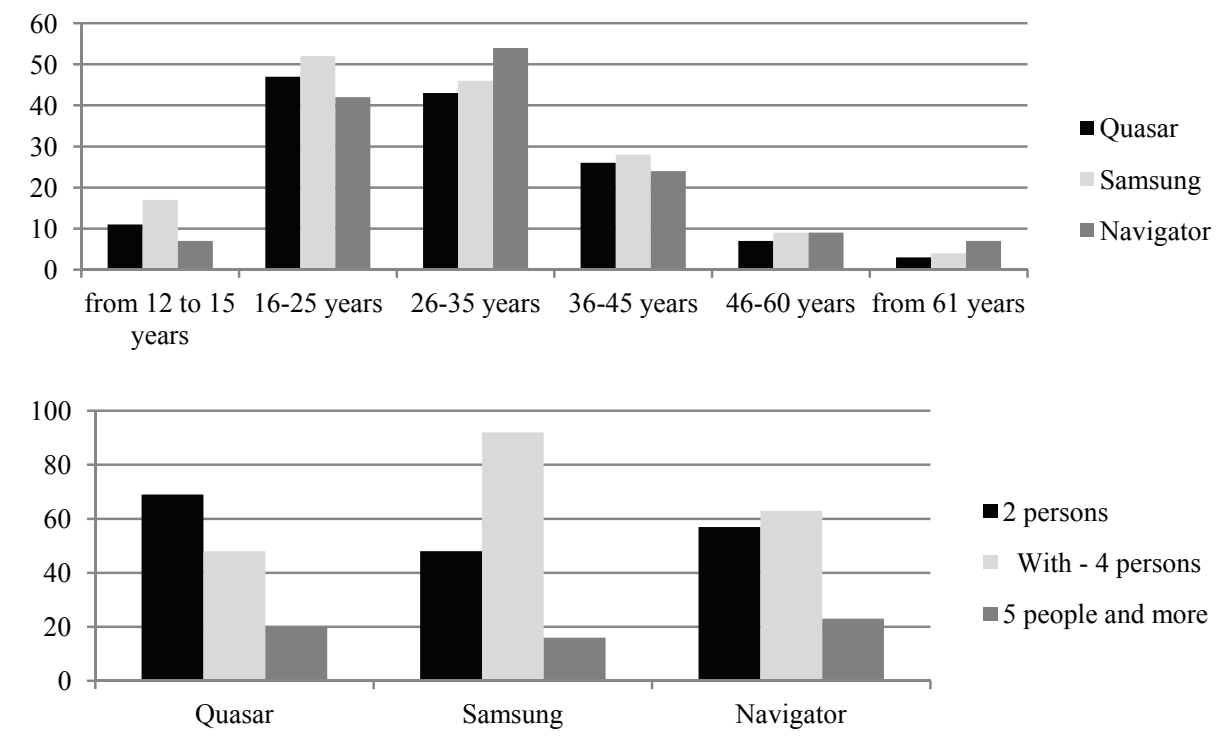

Figure 5. Distribution by composition of families, age of respondents of enterprises Source: Authors' elaboration.

Analyzing Figure 5, we can conclude the segment of respondents aged 26-35 years and 16-25 years living in families with 3-4 people. Figure 6 presents the results of the survey, which show the distribution of life cycle stages of the respondents. 


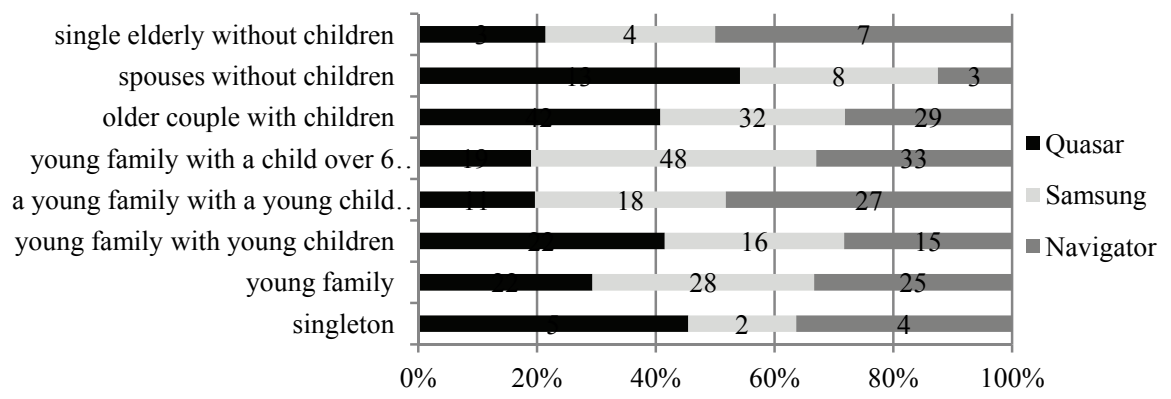

Figure 6. Distribution of respondents according to the life cycle stages of the three enterprises Source: Developed by authors.

As can be seen from Figure 6, the largest segment here is a family of 3-4 persons, aged 26-35 years, with the largest purchase of a computer device by a young family with a child over 6 years of age ${ }^{15}$.

Bludova T.V., Tokar V.V. (2013) ${ }^{16}$ emphasize that computer technologies have a great influence on the development of science, technology, business and many other spheres of human activity. The specifics of different professions play a role in the choice of goods. Figure 7 presents a diagram of the type of profession of respondents. Figure 7 shows that the distribution of respondents by occupation by district has the same characteristics. As you can see, you can select a segment of managers and students. This segment is characteristic of all three enterprises.

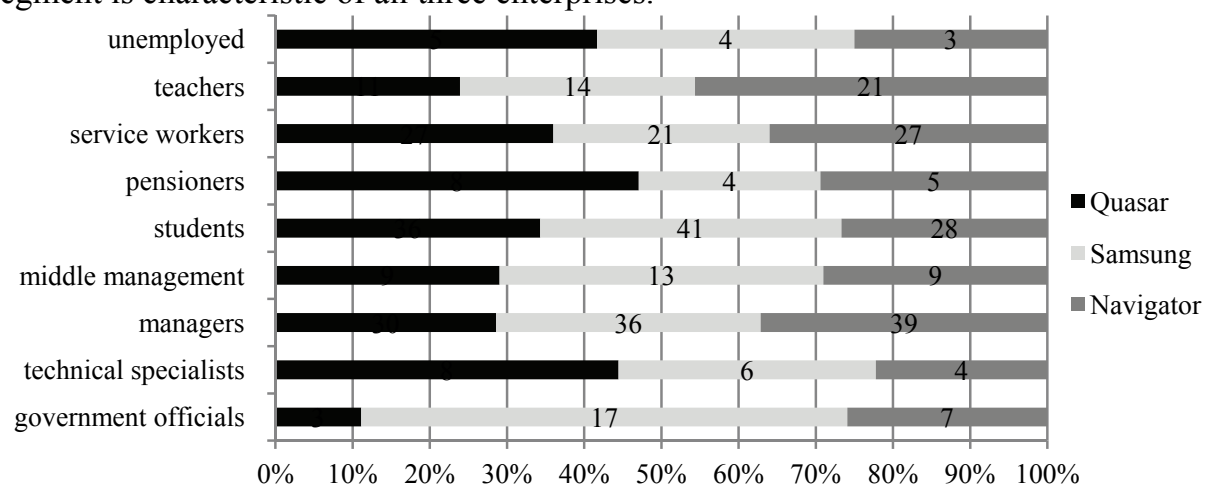

Figure. 7. Distribution of respondents by type of professions of the three enterprises

Source: Developed by authors.

It should be noted that in terms of religious beliefs, almost all respondents (an average of $96.7 \%$ ) turned out to be Orthodox.

Figure 8 presents a diagram of the distribution of respondents by level of education.

\footnotetext{
${ }^{15}$ Kumar, N. (2008). Marketing as Strategy Leading to Successs, Prague: Grada Publishing (in Czech).

${ }^{16}$ Bludova T.V., Tokar V.V. (2013). Modeling of innovation and investment activity in the context of economic security of the enterprise // Effective Economics. - 2013. - № 2. - [Electronic resource]. - Access mode: http://nbuv.gov.ua/UJRN/efek_2013_2_58 (In Ukrainian )
} 


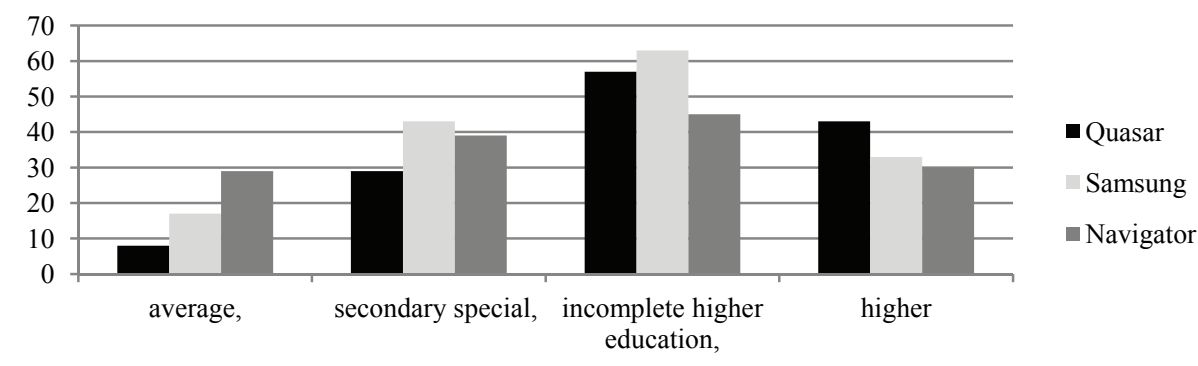

Figure. 8. Distribution of respondents by education level criterion for three enterprises Source: Developed by authors.

Figure 8 shows that the distribution of respondents by level of education has similar characteristics. It is possible to distinguish a segment of students with incomplete higher education.

\section{Results of questionnaires for segmentation by psychographic factors}

The results of the questionnaire for determining the psychographic factors are presented in Figures 9 - 10.

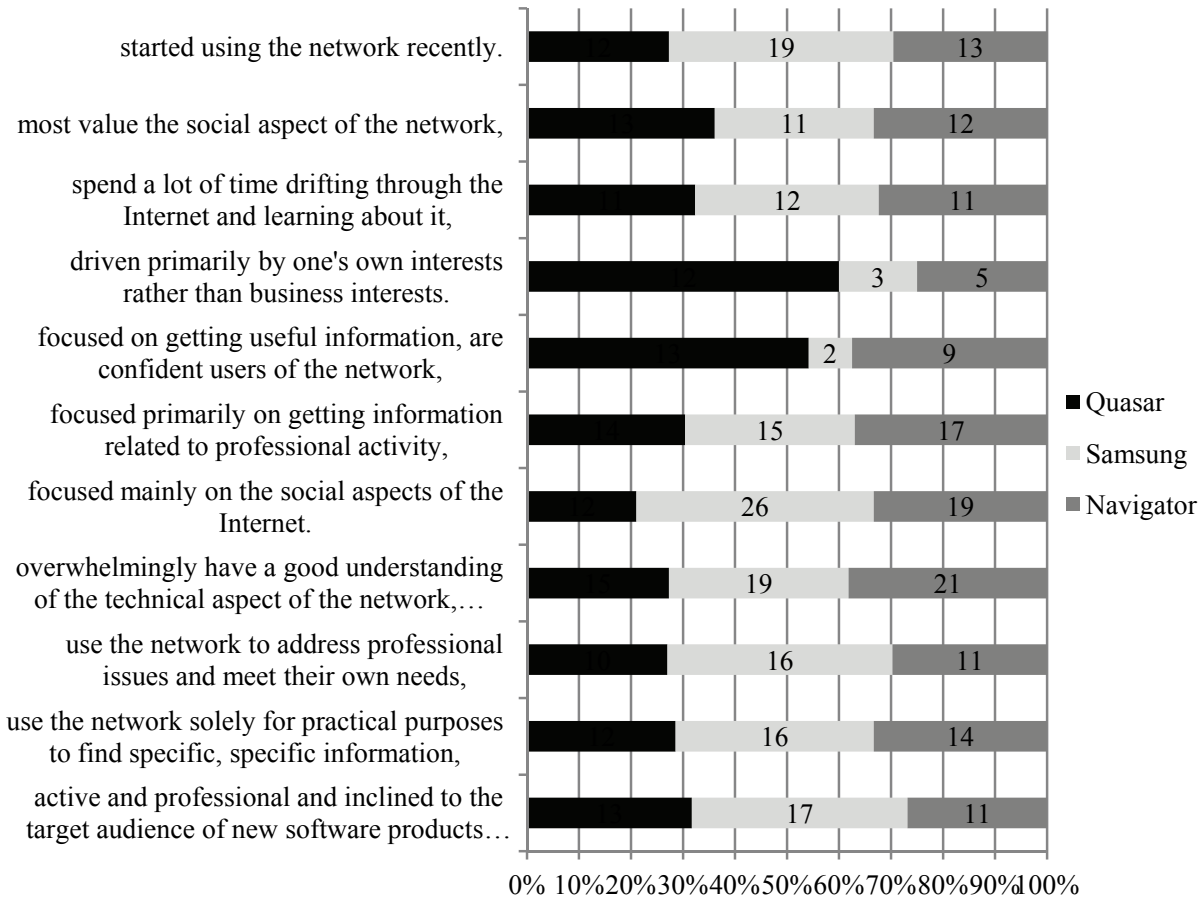

Figure 9. The results of the survey on the psychography of consumers as they refer to themselves Source: Developed by authors. 
Note that psychography is a stable position; feelings experienced by an object, person, or idea that are formed on the basis of ideas and feelings that lead to certain behavior. We form and develop relationships that can be positive or negative, reflecting affection or dislike or being neutral. Relationships are important for advertisers because they influence the consumer response to the product (a positive attitude can be turned into a brand preference). Thought research is used to test how people feel about other people, products, brands, appeals, and current trends. A special role here is played by individuality - these are characteristics of character and mental makeup that distinguish one person from another. The way the consumer views the world, how he/she perceives (with what emotions) and interprets what is happening, how he/she reacts intellectually and emotionally, how he/she shapes thoughts and positions, all of which characterize the consumer's individuality, which makes his/her personality. Figure 9 presents the results of the responses regarding the psychography of the consumers to whom they refer. The answers are uniform, but there is still a noticeable segment of consumers who are focused mainly on the social aspects of the Internet.

Figure 10 shows the results of responses to the consumer's psychological qualities.

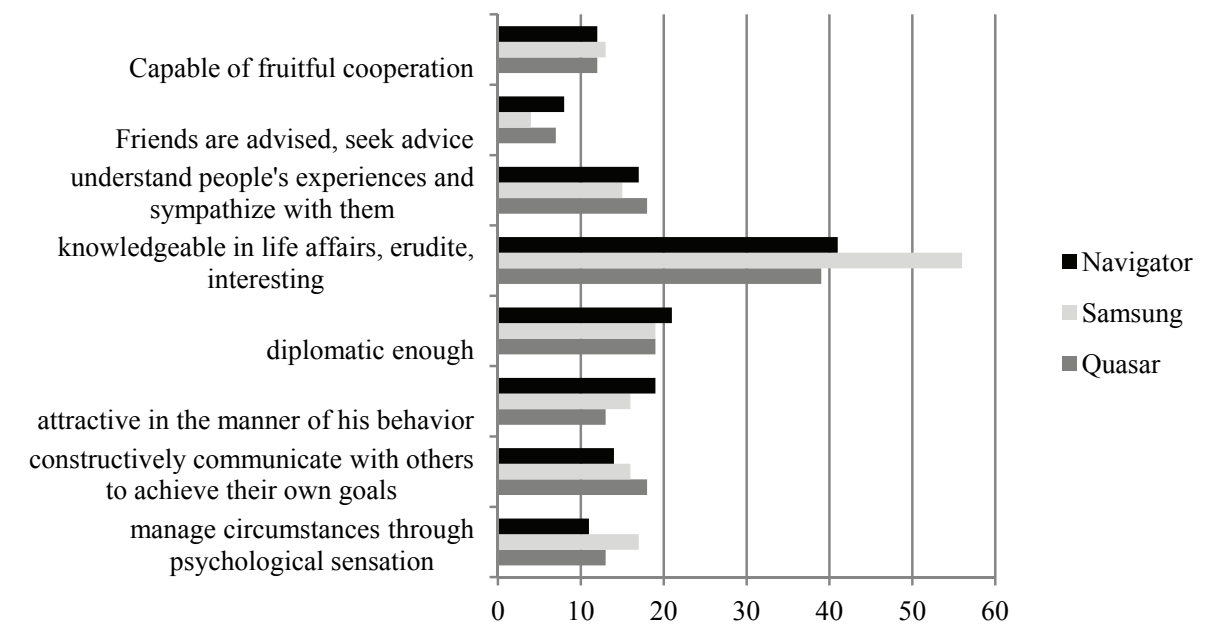

Figure 10. The results of the survey questionnaire on the consumer's psychological qualities Source: Developed by authors.

It clearly distinguishes a segment of consumers who believe that they are erudite, interesting and knowledgeable in life matters. We emphasize that self-awareness is a perception of oneself. Our own image reflects our vision of our individuality and a personal example of strength and weakness. Therefore, the urgent question arises about identifying the character traits that best characterize the consumer and what they think about themselves. Of particular interest is the identification of characteristics that affect the consumer's attitude to various products, advertising, as well as his/her behavior as a buyer.

The survey results for determining social factors are presented in Figures 11-12. The distribution of respondents by social classes is shown in Figure 11, where a significant segment of consumers is in the middle class, in the second place are the poor and in the third place is the upper class. 


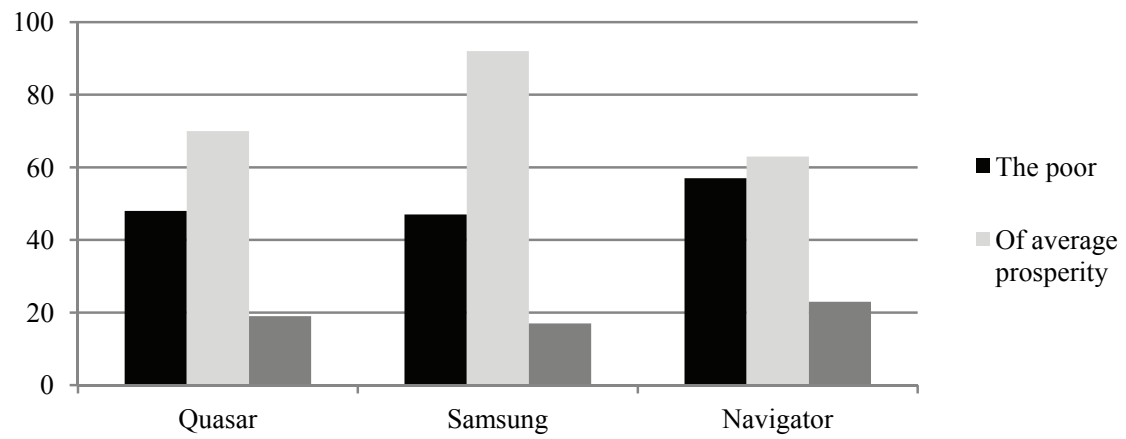

Figure 11. Distribution of respondents by social classes Source: Developed by authors.

The breakdown of respondents by occupation is given in Figure 12, where a significant segment of consumers are employees, second place students and third place entrepreneurs.

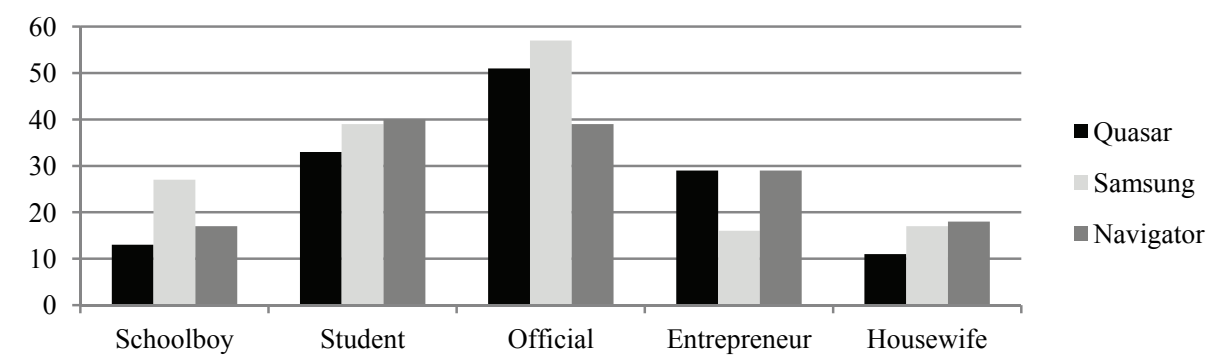

Figure 12. Distribution of respondents by occupation Source: Developed by authors.

Figure 13 presents the results of the responses regarding the devices purchased by the respondents. A significant segment stood out for tablets, followed by smartphone purchases.

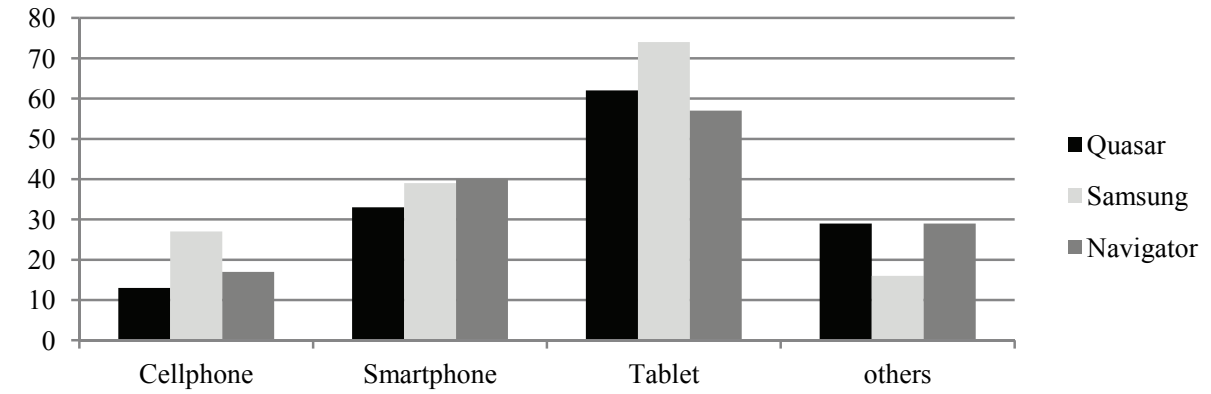

Figure 13. Buying Device Features You give preference to devices by respondents Source: Developed by authors. 
Figure 14 shows the results of the survey of respondents' answers to the question of the characteristics of the devices that were preferred during the purchase.

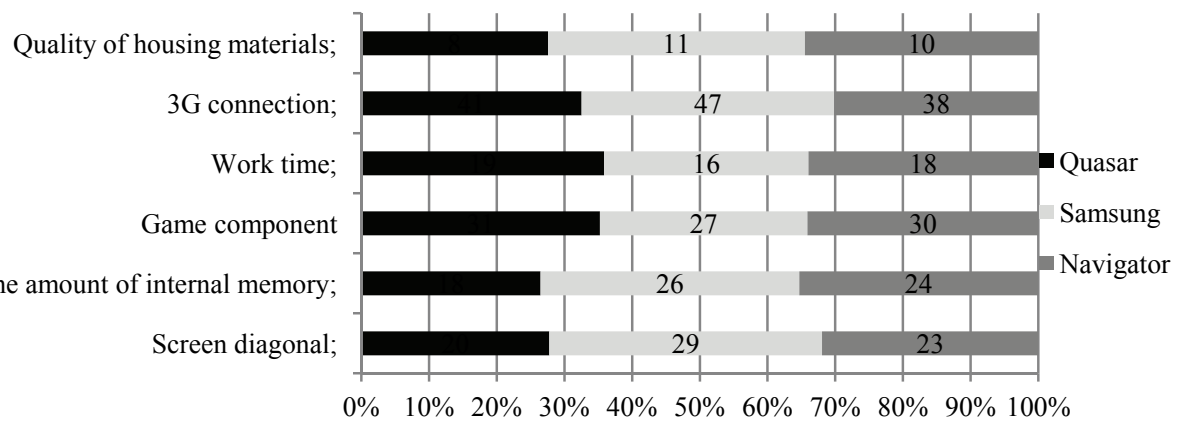

Figure 14. Characteristics of respondents' preferred devices Source: Developed by authors.

As can be seen from Figure 14, the segment of consumers that prefers $3 \mathrm{G}$ connectivity is currently distinguished. In the second place comes the game component.

\section{Conclusions}

Similarly, the questionnaire survey of respondents' answers was processed to evaluate the relevant factors. The results are presented in Table 6 . The best performance is Samsung Electronics Ukraine Company. In second place is Navigator.

Table 6. Evaluation of relevant factors of enterprises

\begin{tabular}{|c|r|r|r|r|}
\hline Enterprise & $\begin{array}{c}\text { What manufacturers } \\
\text { are known to the } \\
\text { respondents }\end{array}$ & $\begin{array}{c}\text { Advantage at } \\
\text { the same } \\
\text { price }\end{array}$ & $\begin{array}{c}\text { The level of prices } \\
\text { for products of the } \\
\text { enterprise }\end{array}$ & $\begin{array}{c}\text { Products are } \\
\text { always on sale }\end{array}$ \\
\hline $\begin{array}{c}\text { Samsung Electronics } \\
\text { Ukraine Company }\end{array}$ & 55 & 44 & high & 57 \\
\hline "Navigator" & 35 & 37 & receptive & 38 \\
\hline "Quasar" & 10 & 19 & receptive & 5 \\
\hline
\end{tabular}

Source: Authors' elaboration.

Thus, we combine the results in Table 7, which presents the hypotheses, individual and segment factors.

Table 7. Confirmation of hypotheses and isolation of the consumer segment

\begin{tabular}{|l|l|}
\hline \multicolumn{1}{|c|}{ Hypothesis (factor) } & \multicolumn{1}{c|}{ Separation of consumer segment } \\
\hline $\begin{array}{l}\text { Most consumers use 6-7 hours a day; } \\
\text { the existing device is not satisfactory in } \\
\begin{array}{l}\text { terms of functional characteristics; } \\
\text { important in choosing is the price and } \\
\text { processor; device purchased up to 1 year } \\
\text { ago (Behavioral) }\end{array}\end{array}$ & $\begin{array}{l}\text { The length of the time corridor for using a computer device is } \\
\text { Consumers who want to buy a new model of computer device. } \\
\text { Consumers who need an up-to-date operating system and then } \\
\text { the size of the built-in and RAM are important. }\end{array}$ \\
\hline $\begin{array}{l}\text { Most consumers are men aged 26-35, } \\
\text { married, have two children, with an } \\
\text { average monthly income of 2000-5000 }\end{array}$ & $\begin{array}{l}\text { Almost all respondents are Ukrainian, and on average half of } \\
\text { the respondents are male and half are female. 26-35 years old } \\
\text { and 16-25 year olds living in families with 3-4 people, with }\end{array}$ \\
\hline
\end{tabular}




\begin{tabular}{|c|c|}
\hline UAH. (Demographic) & $\begin{array}{l}\text { the most likely to purchase a young family computer with a } \\
\text { child over } 6 \text { years of age. Segment of students with tertiary } \\
\text { education. This segment is unique to all three districts. The } \\
\text { following major segments can be distinguished: respondents } \\
\text { with specialized secondary education and higher education. }\end{array}$ \\
\hline $\begin{array}{l}\text { Basically, consumers buy products in } \\
\text { their area if they have a business store } \\
\text { selling computer devices with a network } \\
\text { connection (Geographic) }\end{array}$ & $\begin{array}{l}\text { The hypothesis is confirmed } \\
\text { The segment of managers and students can be distinguished }\end{array}$ \\
\hline $\begin{array}{l}\text { Consumers who use the network to } \\
\text { address both professional and } \\
\text { professional needs are extroverted and } \\
\text { have the potential to be open to the } \\
\text { experience of being (Psychographic) }\end{array}$ & $\begin{array}{l}\text { A segment of consumers focused mainly on the social aspects } \\
\text { of the Internet. } \\
\text { A segment of consumers who think they are erudite, } \\
\text { interesting, and knowledgeable in life. }\end{array}$ \\
\hline $\begin{array}{l}\text { Medium Consumers, Employees Who } \\
\text { Perceive Media Impact on Mass Media } \\
\text { Products } \\
\text { (Social) }\end{array}$ & $\begin{array}{l}\text { A significant segment of consumers are in the middle class, in } \\
\text { the second place are the poor, and in the third place are the } \\
\text { upper class. Considerable segment of consumers are } \\
\text { employees, in the second place - students, and in the third } \\
\text { place - entrepreneurs }\end{array}$ \\
\hline $\begin{array}{l}25-35 \text { year olds who buy devices every } \\
9 \text { months and prefer tablets that come } \\
\text { with a keyboard with computer features } \\
\text { purchased a one to one and a half year } \\
\text { old computer device. }\end{array}$ & $\begin{array}{l}\text { A significant segment is buying tablets, followed by } \\
\text { smartphones. The consumer segment that prefers } 3 \mathrm{G} \\
\text { connectivity then comes out with the game component. }\end{array}$ \\
\hline $\begin{array}{l}\text { The company selected by the consumer } \\
\text { he knows is given priority at the same } \\
\text { price, it is this enterprise, the price level } \\
\text { is perceived and its products are on sale }\end{array}$ & $\begin{array}{l}\text { The best performance of Samsung Electronics Ukraine } \\
\text { company. } \\
\text { In second place is Navigator. }\end{array}$ \\
\hline
\end{tabular}

Source: Authors' elaboration.

Consumers' answers are distinguished by the results of the survey and the analysis of the answers of the respondents above. So, we present segmentation of the market for computer devices with network connectivity in a three-company survey. Thus, Table 5 provides confirmation of the hypotheses and the segregation of the consumer segment.

Note that there is also the danger that if marketers-competitors try too hard to "segment" each other, then the market will be crushed to an unacceptable level and consumers become entangled in the variety of products they are offered.

\section{Bibliography}

Anderson, E. W., Fornell, C., \& Mazvacheryl, S. K. (2004).Customer satisfaction and shareholder value.Journal of Marketing, 68(4), 172-185. Retrieved from http://dx.doi.org/10.1509/jmkg.68.4.172.42723

Baron, S. and Harris, K. (2010). Toward an Understanding of Customer Perspectives on Experiences. Journal of Services Marketing, 24(7), pp. 518-531.

Bludova T.V., Tokar V.V. (2013). Modeling of innovation and investment activity in the context of economic security of the enterprise // Effective Economics. - 2013. - № 2. - [Electronic resource]. Access mode: http://nbuv.gov.ua/UJRN/efek_2013_2_58 (In Ukrainian )

Cliff K (2009) A formative index of segment attractiveness: optimising segment selection for tourism destinations. Ph.D. thesis, School of Management and Marketing, Faculty of Commerce, University of Wollongong 
Dolnicar S, Leisch F (2010) Evaluation of structure and reproducibility of cluster solutions using the bootstrap. Mark Lett 21:83-101

Dolnicar S, Leisch F (2017) Using segment level stability to select target segments in data-driven market segmentation studies. Mark Lett 28(3):423-436

Kotler, P. and Keller, L.G. (2013). Marketing Management, Prague: Grada Publishing (in Czech). Kourdi, J. (2011). Marketing Century: How Marketing Drives Business and Shapes Society, Chichester: John Wiley \& Sons.

Kowalkowski, CH. (2011). Dynamics of Value Propositions: Insights from Service-Dominant Logic, European Journal of Marketing, Vol.45, No:1/2, pp. 277-294.

Kumar, N. (2008). Marketing as Strategy Leading to Successs, Prague: Grada Publishing (in Czech).

McDonald M, Dunbar I (2004). Market Segmentation: How to Do It, How to Profit from It.Elsevier ButterworthHeinemann. Oxford.

T. Bludova (2005). Probability Theory: Educ. guide Lviv. NBU National Bank, 2005- 319 p. (In Ukrainian )

Wallenburg, C. M. and Lukassen, P. (2011). Proactive Improvement of Logistics Service Providers as Driver of Customer Loyalty, European Journal of Marketing, Vol. 45, No: 3, pp. 438-454.

Wiedmann, K.P., Hennigs, N., Pankalla, L., Kassubek, M., Seegebarth, B. and Reeh, M.O. (2010). Online Distribution of Pharmaceuticals: Investigating Relations of Consumers' Value Perception, Online Shopping Attitudes and Behaviour in a Epharmacy Context, Journal of Customer Behaviour, Vol. 9, No. 2, pp. 175-199.

Wood SN (2006) Generalized additive models: an introduction with R. Chapman and Hall/CRC, Boca Raton.

Information about authors:

Natalia Wasilewska - Doctor of Economics, professor UJK,

Jan Kochanowski University in Kielce

Faculty of Social Sciences, Department of Economics and Management,

114/118 Słowackiego St., 97-300 Piotrków Trybunalski,

e-mail: nwasilewska@ujk.edu.pl,

ORCID: 0000-0001-8638-4735

Tatiana Bludova - Doctor of Economics, professor,

Kyiv National Economic University named after Vadym Hetman

Marketing Faculty, Advanced Mathematics Department,

54/1 Prospect Peremogy, Kyiv city

e-mail: bltavl@ukr.net,

ORCID: 0000-0001-7011-5645

Volodymyr Tokar - Doctor of Economics, professor,

Kyiv National Economic University named after Vadym Hetman

Department of International Finance,

e-mail: tokarww@ukr.net,

ORCID: 0000-0002-1879-5855

Oleksiy Kudenko - Assistant of Marketing Faculty

Kyiv National Economic University named after Vadym Hetman

Advanced Marketing Department,

e-mail: alex.kudenko.1989@gmail.com 